\title{
Research on the Quality of Accounting Information Disclosure of Listed Companies in China
}

Danyun Chen *

Shaoxing University Yuanpei College, Shaoxing 312000, China. E-mail: 523919037@qq.com

Abstract: As the main executor of accounting information disclosure, listed companies are more likely to be favored by investors, suppliers, management departments, the public and other stakeholders. They will also be better than non listed companies in the performance of corporate social responsibility, and will disclose more information in the disclosure of environmental accounting information. The information of listed companies is relatively open and transparent. The annual major events public, annual report, interim report, interim report and environmental report are published on the corresponding websites for the convenience of information collection and collation. The quality requirement of accounting information is to meet the needs of stakeholders, so that they can make correct decisions with the useful information. However, there are some problems in the disclosure of accounting information due to the imperfection of the relevant system and the inadequate supervision.

Keywords: Quality of Accounting Information Disclosure of Listed Companies

As early as the 1960s, there were studies on accounting information disclosure abroad, but according to the literature, China began to record it at the end of the 20th century. At present, China has constantly improved the accounting information disclosure system of listed companies, but in recent years, financial scandals continue to occur, such as Sichuan Changhong, Tianhe chemical and other companies. Such events will not only become a stumbling block for the development of listed companies, but also affect the decision-making of information users. Therefore, it is an urgent problem to study the quality of accounting information disclosure of Listed Companies in China and put forward reasonable suggestions.

\section{The quality of accounting information disclosure of listed companies in China}

Accounting information disclosure refers to the direct or indirect disclosure of important accounting information by enterprises. Information disclosure of listed companies is a bridge connecting listed companies and investors, and accounting information disclosure system is the premise to ensure the effective operation of the securities market. The key to the quality of accounting information disclosure lies in whether the disclosure is true and reliable, whether the disclosure is sufficient and timely, and whether the disclosed objects are fair. Accounting information disclosure of listed companies should follow the principle of sufficiency and authenticity. From the perspective of corporate information disclosure, information disclosure is divided into mandatory information disclosure and voluntary information disclosure. Mandatory disclosure is a kind of disclosure method which is required by laws and regulations that listed companies must disclose information in time to ensure investors to make scientific and reasonable investment decisions in time. At the same time, it can also shorten the time of accounting information disclosure of listed companies, so that information users can quickly obtain and use information. Voluntary disclosure is a kind of disclosure method that the regulatory department does not stipulate and the listed companies voluntarily disclose accounting information.

This is an open-access article distributed under the terms of the Creative Commons Attribution Non-Commercial License (http://creativecommons. org/licenses/by-nc/4.0/), which permits unrestricted non-commercial use, distribution, and reproduction in any medium, provided the original work is properly cited. 
The National People's Congress, the Ministry of finance, the CSRC, the Shenzhen Stock Exchange and the Shanghai Stock Exchange have formulated a series of laws, regulations and supervision rules to regulate the accounting information disclosure of listed companies, and formed a series of laws, regulations and supervision rules, led by the company law of the people's Republic of China, the securities law of the people's Republic of China and the criminal law of the people's Republic of China, accounting standards for enterprises and information of companies that issue securities publicly the disclosure content and format standards, the measures for the administration of initial public offering and listing, the measures for the administration of information disclosure of listed companies and other selfdiscipline rules are an integrated legal and regulatory system. The regulatory system of information disclosure of listed companies refers more to the internationally accepted standards, which are relatively high and basically in line with the international standards, promoting the accounting information disclosure of listed companies. The quality of accounting information disclosure has been improved step by step.

\section{Analysis on the quality of accounting information disclosure of listed companies in China}

\subsection{Poor quality of information disclosure}

Due to the existence of fair value and accounting estimates, the accounting information produced in the processing of accounting business has human control factors. Article 18 of the accounting standards for business enterprises - Basic Standards stipulates that "an enterprise shall exercise due care in accounting recognition, measurement and reporting of transactions or events, and shall not overestimate assets or revenues, underestimate liabilities or expenses." This is the requirement of prudence in the quality of accounting information, but some listed companies are trying to avoid the unfavorable accounting information. One is that the disclosure of major events is not enough, which will affect the decision-making of the information users. The other is that the bad accounting information of the company is concealed, and the real situation of the company is not disclosed to the public, which violates the laws and regulations of information disclosure in China.

\subsection{Information disclosure supplement is serious}

This phenomenon refers to the fact that after the listed company publishes or publishes the accounting information such as the annual report and the interim financial accounting report, it will supplement and modify the missing or wrong accounting information. This will not guarantee the authenticity and timeliness of the disclosed accounting information, but also reflects the poor management of the leadership of some listed companies in our country, which does not detect and stop the work errors of employees in time.

\subsection{Lack of comparability and timeliness of information disclosure}

As a management activity, one of the purposes of accounting is to provide the stakeholders with accounting information that reflects the fiduciary responsibility of managers and investors to make decisions. To achieve this goal, accounting information must have eight quality requirements: reliability, relevance, comprehensibility, comparability, substance over form, importance, prudence and timeliness. At present, the methods and forms of accounting information disclosure of some listed companies are not unified and fixed, and there are great randomness and instability, which makes it difficult to compare accounting information vertically or horizontally, and the changing trend of financial status and operating performance of enterprises cannot be intuitively defined. The annual report shall be prepared and disclosed within four months after the end of each fiscal year, and the interim financial accounting report shall be prepared and disclosed within 60 days after the end of the first six months of each fiscal year. Although delaying the understanding of all aspects may make the accounting information more comprehensive, missing the best probation period of the information will make the information less useful. In today's era of rapid information flow, the timeliness of information may be more important than the comprehensiveness of information. Information users should achieve a balance between the pursuit of timeliness and reliability of information.

\section{Suggestions on improving the quality of accounting information}




\section{disclosure of listed companies in China}

\subsection{Improve the effectiveness of internal governance}

Compared with non listed companies, listed companies have more stringent requirements on financial disclosure, which requires not only the constraints of laws and regulations, but also the governance of the company's internal leadership. First of all, a scientific and perfect company system should be established within the listed company, each of which should perform his own duties, do his own work well, without damaging the legitimate rights and interests of the company, and everyone has a corresponding reward and punishment mechanism; second, the leadership should actively play the role of leadership, coordination and motivation, and must play its own leadership role in the organization, and have the ability to influence followers. It can make the salary of the leadership linked with the performance of the company, make the interests of shareholders and leaders interrelated, and improve the work efficiency.

\subsection{Strictly abide by accounting standards and information disclosure standards}

Accounting workers are the main producers and providers of accounting information in enterprises. In the process of providing information, they must not only put their own work under the constraints and norms of laws and regulations, but also have the professional ethics level corresponding to their functions. Enterprises should not only focus on their working ability, but also attach importance to their understanding and implementation of the standards. Accountants themselves should strictly abide by the accounting standards and information disclosure standards, and should not do anything beyond their boundaries; the leadership of enterprises should strengthen the indoctrination of ideas, and take the initiative to train employees when necessary.

\subsection{Strengthen administrative supervision}

China Securities Regulatory Commission, Shenzhen Stock Exchange, Shanghai Stock Exchange, industry association and other institutions constitute the current administrative supervision system of accounting information in China. Each agency should have a clear and detailed breakdown of authority and responsibility. At present, each part is relatively scattered, and there is no specific regulation, which makes it difficult for each agency to coordinate and cooperate with each other. Therefore, we should further improve the specific laws and regulations of administrative supervision, so that each institution can do its own thing, supervise the quality of accounting information disclosure of listed companies from different aspects, strengthen the social pressure of listed companies, and regulate their own behavior.

\subsection{Increasing punishment for information disclosure violations}

For any company or person in charge who violates the accounting information disclosure rules, they should be punished and publicized to the public, strengthen the social influence, and break the concept of "low illegal cost". In 2018, China Securities Regulatory Commission (CSRC) imposed a penalty on the illegal case of information disclosure of Qinshang shares, ordered Qinshang shares to make corrections, gave a warning, and imposed a fine of 600,000 yuan, a warning, and a fine of 300,000 yuan on the person directly in charge, and a fine of 100,000 yuan on the other persons directly responsible. Compared with the punishment of foreign countries, the degree of punishment measures in China's laws is relatively light, and relevant institutions should further increase the punishment for violations, especially for the company's top leaders or executives.

\section{Conclusion}

Information disclosure system is the cornerstone of the healthy development of the capital market and the meaning of the principle of openness. Listed companies and other information disclosure obligors must disclose information in a true, accurate, complete and timely manner in strict accordance with the requirements of laws and regulations to fully protect the investors' right to know.

This paper starts with the current situation of the quality of accounting information disclosure of listed companies in China, conducts some literature research and empirical investigation, analyzes the problems of the quality of accounting information disclosure of listed companies in China, and then puts forward countermeasures and suggestions 
to improve the quality of accounting information disclosure of listed companies in China from two aspects. First of all, from the inside of the company, the leadership should improve the effectiveness of internal governance, and personnel at all levels should strictly abide by accounting standards and information disclosure standards; second, from the outside environment, each regulatory agency should strengthen administrative supervision, and law enforcement departments should increase the punishment for information disclosure violations.

Although there are still some problems in accounting information disclosure of listed companies in China, the quality of accounting information disclosure will be further improved with the efforts of listed companies and all aspects of society in the future.

\section{References}

1. Li W. Empirical research on corporate governance and accounting information disclosure quality_-Based on empirical evidence of listed companies on small and medium-sized boards (in Chinese). Tianjin University of Finance and Economics; 2015.

2. Tan X. Research on environmental accounting information disclosure of listed companies in China (in Chinese). Yunnan University; 2015.

3. Zhang W. Research on accounting information disclosure of listed companies in China (in Chinese). Institute of Fiscal Science, Ministry of Finance of China (in Chinese); 2014.

4. Liu J. Problems and macro thinking of accounting information disclosure in listed companies (in Chinese). China Journal of Commerce 2019; (6): 145-146. doi: 10.19699/j.cnki.issn2096-0298.2019.12.145.

5. Lin W. Analysis of enterprise accounting information quality under the background of Big Data (in Chinese). China Journal of Commerce 2019; (23): 184-185.

6. Liu Y. Research on the influence of enterprise internal control on the quality of accounting information (in Chinese). Research of Finance and Accounting 2019; 116.

7. Li X. Analysis on the violation of accounting information disclosure of listed companies_— Taking Taihua shares as examples (in Chinese). Communication of Finance and Accounting 2019; 16-20.

8. Tian Y. Research on the effectiveness of internal control to the quality of accounting information. Northeast Petroleum University; 2018.

9. Liang H. Thinking about improving the quality of accounting information disclosure of listed companiesBased on the perspectives of corporate governance, internal control and internal audit (in Chinese). Accounting Management (in Chinese) 2019; 57-58.

10. Hang J. On the influence of internal control on the quality of accounting information (in Chinese). China Management Informationization 2019; 22(22): 45-46. 